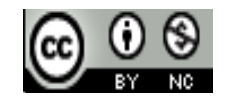

Journal of Education, Teaching, and Learning is licensed under

A Creative Commons Attribution-NonCommercial 4.0 International License.

\title{
LISTENING LEARNING OF INDONESIAN FOR SPEAKERS OF OTHER LANGUAGES (BIPA) FOR ACADEMIC PURPOSES
}

\author{
Widi Astuti ${ }^{1)}$, Nurhadi Bewe ${ }^{2)}$ \\ ${ }^{1)}$ Universitas Negeri Yogyakarta, Yogyakarta, Indonesia \\ E-mail:widi.astuti2016@student.uny.ac.id \\ ${ }^{2)}$ Universitas Negeri Yogyakarta, Yogyakarta, Indonesia \\ E-mail:nurhadi@uny.ac.id
}

\begin{abstract}
Indonesian is now increasingly in demand to be studied by foreign speakers for various purposes. One of the purposes for foreign speakers to learn Indonesian is related to academic purpose. BIPA learning with academic purposes has different characteristics from BIPA learning in general. This study aims to describe listening learning in the BIPA program for academic purposes at Universitas Negeri Yogyakarta based on the aspects of learning preparation and implementation which includes learning activities, learning materials, learning media, learning assessments, problems, and solutions in learning. The subject of this research is a lecturer of listening skills in the BIPA program for academic purposes in the class of Yunnan Minzu University, China. This research used a descriptive qualitative method. Data collection was carried out by observation, interviews, and document study. Data analysis techniques include data reduction, data display, and verification. The validity of the research data was carried out using triangulation methods. The results showed that the learning preparation was carried out by making a syllabus and developing learning materials. Listening learning activities were carried out through pre-listening, while-listening, and post-listening activities. Listening learning materials tailored the academic needs and adjusted to the speaking skills that learners will learn. The learning media used are handouts, audio, and video that were connected from the laptop to speakers and/or projectors. Learning assessment was carried out at the middle of the semester and the end of the semester. Problems encountered in learning include a technical problem and a non-technical problem. To overcome technical problems, the lecturer reported this to the program manager for improvement, while for non-technical problems, the lecturer was proactive to ask the students. Based on the results of this study, it can be concluded that the planning and implementation of listening learning in the BIPA program for academic purposes is following the principles of learning listening in a second or foreign language. However, some things need attention related to technical and non-technical problems that occur so that they can be minimized.
\end{abstract}

Keywords: Learning; Listening; BIPA; Academic Purposes

\section{INTRODUCTION}

Along with the strengthening of Indonesia's position in various fields of life, the presence of Indonesian is considered. Foreign speakers with various backgrounds and purposes learn Indonesian. Learning Indonesian for foreigners became known as the Indonesian for speakers for other languages or BIPA program. This program can be implemented both in student countries and coming directly to Indonesia. BIPA program which aims for academic interests is included in BIPA learning for academic purposes.
BIPA students with academic purposes usually have exceeded the basic level (Kusmiatun et al., 2017a).

In general, the BIPA program aims for foreign speakers to master Indonesian language skills so that they can communicate orally and in writing (Muliastuti, 2017). These language skills include listening, speaking, reading, and writing. Within these four skills, there is also vocabulary and grammar material. Besides, the BIPA program also aims to make foreign speakers have an understanding or knowledge of Indonesian culture. The knowledge of Indonesian culture that is taught can be in the form of languages that they will use in their daily communication, such as how learners greet 
someone, for example by using "Pak"/"Bu"/"Mbak"/"Mas". This is based on the principle that language and culture teaching cannot be separated. Lack of sociocultural, factual, and contextual knowledge of the target language can be an obstacle to understanding speech because language is used to express culture (Anderson \& Lynch, 1988).

BIPA learning with academic purposes does not have clear and standardized competency targets (Kusmiatun, 2017c). The lack of clarity on the achievement of standardized and clear competency targets has made BIPA program organizers develop their achievement targets and competencies. This will certainly affect the planning and learning process of the BIPA program. The lecturers in the regular class stated that they had difficulty if BIPA students with academic purposes could not master the Indonesian language. Students who do not master Indonesian will tend to be passive in class. Therefore, BIPA students with academic purposes need to be tested for their Indonesian language proficiency before entering the regular class (Kusmiatun, 2019). This is done so that lecturers can find out the abilities and skills of these students in using Indonesian.

One of the language skills learning in the BIPA program for academic purposes that needs special attention is listening. This is following the findings of Kusmiatun et al. (2017b) which stated that BIPA students with academic purposes prioritize speaking and listening skills as learning materials in BIPA learning. This can be done because listening and speaking are activities carried out by students every day, especially if students live and study in Indonesia so that the need for mastery of these skills is very high. However, Astuti (2020) found that listening learning in the BIPA program for academic purposes at Yogyakarta State University and Ahmad Dahlan University still encountered various difficulties. From the learner's point of view, the factors of vocabulary, speed of speech, and speaker accent make it difficult for learners to learn to listen. Besides, learners stated that they needed more listening practice to hone their listening skills. Anxiety and lack of confidence when listening is also often experienced by most learners. Therefore, the process of preparing and implementing listening learning needs special attention to minimize these difficulties so that the development of the listening ability of learners can be achieved.

Various difficulties experienced by BIPA students can occur because they listen to Indonesian as a second language or foreign language. The process of listening to the first and second languages or languages that have differences in input processing. Vandergrift \& Goh (2009) stated that cognitive processes occur very quickly when learners listen in the first language, namely top-down and bottom-up processes, to achieve understanding moving flexibly. On the other hand, because of language limitations, second language listeners cannot automatically process everything they hear. The success of listening in a second language or language depends on the degree to which the listener can efficiently coordinate bottom-up and top-down processes. This can improve through listening learning.
However, learning to listen to a second or foreign language for some language learners is something that makes learners anxious. As expressed by Zhang (2012) in her research which stated that often learners of English as a foreign language in China feel frustrated in learning to listen so that it has an impact on students' low listening ability. Besides, students sometimes have difficulty listening to a second language or a foreign language because when listening, students must activate all their sub-skills, such as receiving input, understanding input, remembering input, evaluating input, and responding to input (Renukadevi, 2014). Understanding speech in a second language or a foreign language is not as easy as understanding speech in the first language. Therefore language teachers must understand the various difficulties experienced by language learners when listening and teach various listening strategies so that students can improve their listening skills (Saraswaty, 2018). Therefore, listening skills teachers need to pay attention to various aspects so that listening learning can run well.

Listening learning in the BIPA program needs to pay attention to various aspects so that it can influence the development of listening skills of students. BIPA lecturer also needs to understand that BIPA students are generally adult learners who already have a lot of knowledge and insight and have varied goals in learning Indonesian (Suyitno, 2008). These things certainly have implications for the BIPA learning process so that teachers need to pay attention to several aspects of learning, including learning objectives, materials, media, and evaluation (Suyitno, 2005). These various aspects need to be considered properly so that the objectives of BIPA learning, especially listening can be achieved. Listening learning in BIPA program with academic purposes has special characteristics in learning. BIPA students with academic purposes certainly need listening material related to the academic world, for example listening to discussions, listening to debates, and so on. Besides, the characteristics of BIPA learning for academic purposes are the use of standard language in the learning material (Kusmiatun et al., 2017b).

Beside learning materials, learning media are things that need to be considered in learning listening. Listening learning requires audio and audiovisual media. Usually, the audio or video contained on a laptop or computer will be connected to speakers and projectors so that learners can listen to it. Therefore, supporting factors such as speakers, projectors, and even cables connecting these devices must be able to function properly so that language voices can be heard clearly by students.

The learning process will never be separated from the evaluation. Evaluation is needed to determine the quality of learning that has been done. Besides, with the evaluation, teachers can also find out what competencies have, not and are not yet mastered by students so that teachers can compile a follow-up on this (Nurgiyantoro, 2012). In listening skills, teachers usually use a test form to measure students' listening comprehension. This test can be structured concerning the type of listening being evaluated. Brown 
(2004) stated that there are four types or types of listening, namely intensive listening, responsive listening, selective listening, and directive listening. Each of these types has a different type of test. Besides, a listening assessment can be done using authentic assignments (Brown, 2004; Nurgiyantoro, 2002). In BIPA learning for academic purposes, the teacher provides a proportion of the assessment to determine the student's final grade, namely participation in-class learning, assignment scores, midterm exam scores, and final semester test scores (Kusmiatun et al., 2017a).

Research related to the implementation of BIPA learning has been carried out by several researchers. First, research by Sari, Sutama, and Utama (2016) explained the implementation of BIPA learning at the Sekolah Cinta Bahasa, Ubud, Bali. Second, Azizah, Hs, Lestari (2012) explained the implementation of the BIPA learning program for the Critical Language Scholarship (CLS) at the Faculty of Literature, State University of Malang. Third, Agustina (2013) conducted research related to the implementation of BIPA learning at UPT P2B Sebelas Maret University, Surakarta. Fourth, Kurniawan et al. (2019) reviewed the implementation of the BIPA program and its learning outcomes.

Fifth, research related to teaching listening in a foreign language was conducted by Yusnida, Muslem, \& Manan (2017). Based on the research results of Yusnida, Muslem, \& Manan (2017), the preparation and implementation of teaching listening to English as a foreign language has been carried out well. The two teachers who were the research subjects made different learning preparations. Learning material is taken from various sources. Teaching techniques and methods are following the theory of teaching listening in foreign languages. The two teachers also conducted different evaluations to measure students' listening ability. However, both of them did formative and summative tests when teaching listening.

The research that has been carried out by these researchers provides an overview of how to prepare and implement BIPA learning. However, the four studies did not discuss specifics related to listening learning for academic purposes. Meanwhile, research related to teaching listening to English as a foreign language has the same position as listening learning in the BIPA program. Therefore, it is necessary to conduct research related to the preparation and implementation of listening learning for academic purposes.

One of the BIPA listening learning programs for academic purposes is at Yogyakarta State University (hereinafter written as UNY). UNY is known as one of the educational institutions that have been implementing the BIPA program for a long time. Since 2013, Yunnan Minzu University (hereinafter written as YMU), one of the universities in China has collaborated with UNY in the form of a credit transfer program at the Faculty of Language and Arts (Lestyarini, 2017). YMU students are BIPA students who are at the intermediate level. The courses taught are related to the academic realm because these students are BIPA students with academic purposes. The BIPA students have been taking Indonesian language courses at their home universities for four semesters. Then in the fifth and sixth semesters, they deepened their Indonesian language skills in Indonesia.

Planning and implementing listening learning in the BIPA program for academic purposes is very important for teachers to do. If the planning and implementation of listening learning of the BIPA program with academic purposes run well, of course, it has positive implications for the mastery of listening skills of learners. Therefore, to provide an overview of listening learning in the BIPA program for academic purposes, this study focuses on the process of preparation and implementation of learning which includes activity, material, media, and evaluation of learning at YMU class in UNY.

\section{MethodOLOGY}

This research is a descriptive qualitative study. Qualitative research is used to examine the condition of natural objects (Sugiyono, 2013). This research is then described with data in the form of words. This study describes the learning process of listening in the BIPA program with academic purposes at the YMU class in the Language and Arts Faculty, UNY. The subject of this research is a listening skills lecturer who teaches the BIPA program for academic purposes at the YMU class. The data collection techniques used were observation, interview, and document study. Observations were made to determine the listening learning process. Interviews were conducted to determine the process of preparation and implementation of listening learning. Document studies which include syllabus and learning material handouts were carried out to determine the aspects of listening learning.

This research procedure was data collection, data classification, data analysis, and reporting of research results. Data collection was the first step in carrying out this research. The first data collection was done by making observations to determine the learning process of listening. After making observations, the researcher conducted interviews with the lecturer to confirm the observations that had been obtained previously. Besides, researchers also analyzed documents in the form of syllabus and learning material handouts provided by the lecturer. After carrying out the data collection stage, the next step was data classification. The data that has been obtained are then classified based on the aspects studied, namely the preparation and implementation of learning which consists of learning materials, instructional media, learning evaluation, problems in learning, and solutions in learning. The next stage was data analysis based on each classified aspect. The last stage is reporting the research results. The data that has been analyzed is then concluded and then compiled in a research report. The data analysis technique used was the interactive analysis techniques. Interactive analysis techniques were performed by reducing data, presenting data, and conclusion drawing/verifications which are carried out simultaneously (Miles \& Huberman in Sugiyono, 2013). Data reduction is done by summarizing and sorting the data according to the research objectives 
based on the results of interviews, observations, and document studies. Researchers focused on data related to the preparation and implementation of listening learning in the BIPA program for academic purposes. After the data is reduced, the data is presented in the form of narrative text based on each category, namely (1) learning preparation and (2) learning implementation which includes (a) learning activities, (b) learning materials, (c) learning media, (d) learning evaluation, and (e) learning barriers and solutions. After the data is presented, conclusions are drawn in the form of findings in the process of preparation and implementation of listening learning in the BIPA program for academic purposes at YSU. These findings are in the form of a description of the process of preparation and implementation of listening learning which includes learning activities, learning materials, learning media, learning evaluation, constraints and solutions in learning listening to BIPA for academic purposes at UNY. The validity of the data was done using the triangulation of methods.

\section{RESULTS AND DISCUSSION}

\section{A. Results}

This study resulted in findings related to the preparation of learning and the implementation of listening learning in the BIPA program for academic purposes. Implementation of learning includes learning activities, learning materials, learning media, learning evaluation, problems and solutions in listening learning.

\section{1) Listening Learning Preparation}

Listening learning in the BIPA program with academic purposes at YMU class combined with speaking learning. Each learning theme will be divided into two meetings, with the first meeting for listening activities and the second meeting for speaking activities. However, the focus of this research is learning listening skills only. Listening to teaching is carried out with a duration of 100 minutes per meeting. There are 16 meetings in one semester. Before carrying out learning in class, the lecturer did learning preparation.

The lecturer stated that before the beginning of the listening teaching activity, he made a syllabus at the beginning of the semester. The syllabus is a reference to the implementation of learning for one semester. The syllabus is then given to the program manager so that the program manager can find out the details of the activities during lectures. At the time of compiling the syllabus, the lecturer includes what material he will teach. In this process, the lecturer determined the material by considering the needs and purposes of BIPA learners.

Based on the results of the interview, the lecturer prepared the material based on the needs and purposes of learners to learn Indonesian. BIPA students in the YMU class are students who have also studied for two years at their home university so that the lecturer adjusts their learning material to the level of the learners' ability. After making the syllabus, every week before lectures begin, the lecturer stated that he will make learning materials that are presented in the form of handouts.

\section{2) Listening Learning Implementation}

The implementation of listening learning is divided into learning activities, learning materials, learning media, learning evaluation, problems, and solutions in listening to learning. The following is an explanation of each of these aspects.

\section{a) Listening Learning Activities}

Based on the results of the interview and observations, it is known that the listening learning process consists of three stages, namely pre-listening, while-listening, and postlistening. This is as stated by the following lecturer. There are three pre-listening activities carried out by the lecturer. First, the lecturer greets and asks how the students are. This is done so that students can shift their focus to the lecturer because usually they are still playing on their cell phones or talking to their friends. This activity can be referred to as learner conditioning to be ready to receive learning material. Second, the lecturer leads to a discussion by looking at pictures and accompanied by questions related to pictures. The picture is adjusted to what topic will be listened to that day. When discussing these questions, the lecturer asks students to express their opinions. Besides, each topic is associated with the learner's culture so that learners can express their opinions from the perspective of their culture. Third, the lecturer will introduce the vocabulary that will be used in listening. Based on observations, it is known that how to introduce vocabulary is done by discussing the vocabulary that will be used one by one and asking students to make sentences using these vocabularies orally. Besides, in this pre-listening activity, the lecturer also conveyed the learning objectives for the day.

In listening activities, the lecturer stated that he would play audio or video. He will play the audio or video twice. In the first round, he intended for students to recognize, listen and fill in the answers, while the second round was intended for students to confirm their answers.

Finally, post-listening activities are carried out by discussing listening answers together. The lecturer discusses the answers by listening by discussing one by one of the questions and answers. If there is a student whose answer is not correct, the lecturer will repeat the recorded part of the question so that the student can find out the correct answer immediately. Besides, the lecturer sometimes gives paraphrasing assignments for this post-listening activity.

\section{b) Listening Learning Materials}

Listening to learning materials in the BIPA program for academic purposes are associated with speaking skills. For example, at the first meeting, the speaking skills to be taught were interviews so that at the meeting, the listening activity was listening to interviews. In addition to listening to interviews, in the first semester, there is material on listening to discussions, debates, and folk tales. 
The lecturer stated that he developed learning material by taking it from the internet and revising the language used. The lecturer usually edited so that the language used is following standard Indonesian grammar. Edited learning materials are then arranged in the form of handouts. One handout is used for a listening and speaking skills theme. Besides, the material in the form of audio was developed independently with colleagues, while the material in the form of the video was taken from Youtube.

\section{c) Listening Learning Media}

Lecturer used learning media in every listening lesson. The learning media used were handouts, audio, and video. The handout and audio are made by the instructor himself by asking colleagues for help, while the video is captured from Youtube. If the lecturer used audio, he will connect their laptop with speakers, whereas if he used video, he will use the projector and speaker.

\section{d) Listening Learning Evaluation}

Based on the research, the listening evaluation in the YMU class was carried out in the middle of the program and at the end of the program. Based on the form, evaluation is carried out using test techniques. During the midterm exam, the lecturer played a news recording made by the lecturer. The form of the test was a combination of an open-ended response to a question and an interpretation assignment. The lecturer made proportions for the final assessment of listening and speaking skills. Based on the document study, the evaluation of listening and speaking using the following proportion of assessments: attendance and activeness during lectures is $10 \%$, listening and speaking assignments/practices is $25 \%$, UTS is $30 \%$, and UAS is $35 \%$.

In every listening learning meeting, the lecturer gave the task to train students to listen to Indonesian. The lecturer provided various task to develop listening skills, namely completing gaps in the text (listening cloze), evaluating statements based on listening (true-false), open-ended questions (essay), or interpreting what is read. The lecturer provided feedback on each student listening assignment but does not provide a score for the assignment. The score was given when the students have practised speaking as a combination of listening learning.

\section{e) Problems and Solutions in Listening Learning}

Listening to learning in the BIPA program for academic purposes in the YMU class has problems. There are two types of problems. The first one is technical problems, such as sometimes the cable didn't work or the laptop didn't connect to the projector. The second problem is about the learners who didn't the learning material is silent. Since the students are from the same country, they usually ask their friends what they don't understand using their language (Mandarin).

To overcome technical problems, the lecturer usually come to class early to make sure all the equipment is functioning properly. Besides that, the lecturer has reported equipment damage to the BIPA program manager so that it can be repaired immediately. Although trivial, technical problem will waste several minutes of learning time and can disturb the mood of students. Therefore, the lecturer will ensure that various equipment functions properly before learning begins.

The second problem is that often students are not able to grasp the learning material well but they are silent. So that the lecturer knows what the student's difficulty is, the lecturer approached the student one by one and actively asked the difficulty in listening. This method is considered effective because there are not too many students in the class (12 students) so that lecturer can pay attention and identify the difficulties experienced by each student.

\section{B. Discussions}

Listening Learning in a second language or a foreign language is different from listening to learning in the first language. This is because learners will listen to language speech that they don't often hear, so learners need special strategies to listen well. Learning listening in a second language or a foreign language needs attention because listening skills are basic skills for the development of other language skills. This is following the opinion of Rost (2011) which stated that listening is the key to the development of other language skills. When someone can listen well, of course, they will be able to respond appropriately when communicating.

Listening learning in the BIPA program for academic purposes at the Faculty of Languages and Arts, UNY carried out simultaneously with learning speaking skills. Making syllabus and developing learning materials are part of learning preparation. The syllabus is very important in a lesson. Preparing the syllabus thoroughly can make the classroom atmosphere livelier because students are actively involved in learning (Tokatli \& Kesli, 2009). The syllabus can be used as a contract, plan or as a means of learning and teaching (Parkes \& Harris, 2002). The syllabus serves as a contract between the lecturer and student which usually lasts one semester. The syllabus regulates the responsibilities of the lecturer and students in various tasks, such as attendance, assignments, examinations, and others. This has also been reflected in the syllabus made by the BIPA lecturer. The BIPA lecturer delivered the syllabus presentation at the first meeting so that each student understand how their lesson plans in one semester.

The implementation of listening learning in the BIPA program with academic purposes divided into three activities, namely pre-listening, while-listening, and post-listening activities. The first pre-listening activity is filled with learner conditioning (asking for news or asking about topics that are currently being discussed in Indonesia) so that learners can immediately prepare and focus on learning. Besides, at the pre-listening stage, the lecturer also discusses the topics to be studied and introduces the vocabulary that will be used in listening.

Kusmiatun (2015) stated that in the early stages of learning BIPA, BIPA instructor can greet; ask and answer questions with learners about feelings, health, weather, and 
so on; discuss related to the topic; ask for new vocabulary; asking for assignments; and explain the objectives and material to be studied. Kusmiatun (2015) added that the instructor can ask something that is or will be studied so that learners can recall past vocabulary and learning materials. Richards (2008) also stated that in the pre-listening stage, teachers facilitate learners to be able to activate old knowledge to receive new knowledge. These things have been done by the lecturer in the YMU class so that students are ready to carry out listening activities.

Besides, in this pre-listening activity, the lecturer also incorporated learner culture into the topic discussion. The lecturer asked about topics they would study from the perspective of Chinese culture. This is intended so that learners can express their opinions verbally to contribute positively to the development of their speaking skills. For example, in the activity of listening to folk tales, the lecturer asked whether there were Chinese folk tales whose contents were almost the same as Indonesian folk tales. The inclusion of source culture into target language learning is recommended in learning a second language or a foreign language. As stated by McKay (2003) that the target and source cultural content should be equally represented in foreign language teaching so that learners can identify differences in the original culture and the target culture so that they can have good intercultural communication skills.

In this listening activity, learners do a task to measure their understanding of listening. The types of tasks carried out by learners include completing gaps in the text, answering questions according to recording, evaluating the truth of a statement based on recording (true-false), and interpreting the text. Giving practise or training to BIPA students is good for developing language skills (Kusmiatun, 2015). The lecturer gave an authentic task in learning to listen. Brown (2008) stated that authentic assignments are one of the suggested tasks in listening to learning so that learners can develop their communicative competences. Nurgiyantoro (2011) added that authentic tasks such as interpreting texts are needed in real life. Thus, the teaching of listening to the BIPA program with academic purposes in YMU class has accommodated this principle.

The post-listening activities in the BIPA program for academic purposes in the YMU class are filled with discussion activities. The lecturer doesn't provide a score, but feedback on assignments. The lecturer always monitors the learner's comprehension and provides feedback on each lecture listening by discussing the student's answers and discussing the parts that the learners do not answer correctly. This is following what Brown (2004) and Richards (2008) conveyed that such feedback is required in a second language or foreign language learning classes. In addition to the discussion, sometimes the lecturer also asks learners to make interpretations of the input that has just been listened to in the written form. This kind of authentic assignment will develop the learner's ability to use the target language.

Tomlinson (1998) stated that learning material is something that is used by teachers and learners in the learning process. Learning materials serve to increase knowledge and or language experience. The learning material in listening learning is adjusted to speaking competence because learning both become one subject. Therefore, the listening material in the YMU class is an example or model in speaking practice that will be carried out by learners. For example, one of the speaking competencies is that learners can tell storytelling. In listening activities, students will hear a recording in the form of a fairy tale. Thus, it can be said that listening learning is taught with an integrative approach with other language skills. As stated by Andayani (2015) that in BIPA learning, an integrative approach can be done by integrating one language skill with other language skills.

The preparation of this teaching material can also integrate it with topics that BIPA students like. Based on research conducted by Kusmiatun (2016), BIPA students from China like the topic of entertainment in learning to listen. These findings can be used by BIPA teachers to compile listening teaching materials according to the interests and needs of learners.

The essence of the material contained in the teaching materials in the BIPA program for academic purposes must refer to the use of language in the academic world, for example, the use of standard Indonesian according to the rules in PUEBI (Pedoman Umum Ejaan Bahasa Indonesia), including the use of standard vocabulary and effective sentences (Susilo, Rozak, \& Juwanda, 2017) The teaching materials used in learning listening for academic purposes in YMU class have accommodated these things. The handouts made by the lecturer have used standard language and effective sentences.

The use of learning media in listening to learning in the BIPA program for academic purposes needs to be considered by the teacher. Learning media is anything to convey messages or information in the teaching and learning process (Smaldino et al., 2012; Arsyad, 2014). The lecturer in YMU class used audio, video, and handouts in listening learning. The quality of the audio/video and the presence of speakers are very important in learning to listen. If there is interference with the media, the student's comprehension can affect because they cannot hear clearly (Azmi et al., 2014). Therefore, the lecturer must pay attention to the quality of the recording so that students can listen clearly because most of the audio is made by the teacher himself. However, in listening to learning in YMU class, there are sometimes disturbances in the equipment used, such as malfunctioning of the cable to connect the laptop to speakers or projectors. This is also experienced in learning listening at all levels and programs. Aryana \& Apsari (2018) reported that one of the difficulties or problems experienced by teachers in teaching listening to English is the malfunction of the cable to connect to speakers and computers. Therefore, the lecturer anticipates arriving early to check the condition of the equipment to be used in learning and to report the damage to the tool to the BIPA program manager.

Evaluation activities are an inseparable part of the learning process. Because listening learning was carried out simultaneously with speaking learning, the lecturer 
evaluated the student's listening comprehension during midterm and final semester exams. The lecturer continued to monitor the student's comprehension through assignments and discussions every meeting. The lecturer was also actively asking the students to find out how the student's listening ability is. This is also related to the problem in learning. Students sometimes did not understand the material but they were only silent so that the lecturer needs to be active to provoke student responses through questions and answers and discussion of the listening tasks that have just been carried out.

Based on the findings and discussion, the lecturer did prepare and implement listening learning. Listening learning in the BIPA program for academic purposes in the YMU class has applied the principles of a second language or foreign language learning, both preparation and implementation of learning. With the application of the principles of a second language or foreign language learning, listening learning activities can run well. Therefore, learning objectives can be achieved.

\section{CONCLUSIONS}

Listening learning to a second or foreign language is different from listening learning to a first language. Listening learning in the BIPA program for academic purposes at YMU was implemented integratively by learning speaking skills. Learning preparation was carried out by making a syllabus and learning materials. The implementation of listening learning was carried out in three stages of activity, namely pre-listening, while-listening, and post-listening. Listening learning materials in the BIPA program for academic purposes was developed based on the needs of learners in the academic realm and is adjusted to the competence of speaking skills. The learning media used include audio, video and handouts. The evaluation was carried out twice in one semester, namely at the middle of the semester and at the end of the semester. The lecturer always gives feedback to students at every meeting. Problems in listening learning consist of technical problems and non-technical problems. The solution to technical problems was by reporting to the program manager to be fixed and non-technical problems to be overcome by asking students about the difficulties they were experiencing.

Based on the results of this study, it can be concluded that the planning and implementation of listening learning in the BIPA program for academic purposes is following the principles of learning listening in a foreign language. However, some things need attention related to technical and non-technical problems that occur so that they can be minimized.

Based on the findings of this study, several things can be suggested as follows. First, a BIPA instructor in other language skills is expected to be able to prepare and implement BIPA learning well so that the learning objectives can be achieved well too. Second, other researchers are expected to explore other language skills in other BIPA programs to add to the study of the implementation of BIPA learning for academic purposes.

\section{ACKNOWLEDGEMENT}

Gratitude is conveyed to the Directorate of Research and Community Service for funding this research through the Institute for Research and Community Service, Universitas Negeri Yogyakarta so that it can be carried out well.

\section{REFERENCES}

Agustina, R. (2013). Implementasi Pembelajaran Bahasa Indonesia bagi Penutur Asing di UPT P2B Universitas Sebelas Maret Surakarta. Thesis. Surakarta: Universitas Sebelas Maret. Unpublished.

Andayani. (2015). Integrasi Model Pemahaman Budaya Lokal dalam Pembelajaran Bahasa Indonesia bagi Penutur Asing dengan Pendekatan Integratif. Paper in Seminar Nasional dan Launching Asosiasi Dosen Bahasa dan Sastra Indonesia (ADOBSI). Surakarta: Universitas Sebelas Maret.

Anderson, A. \& Lynch, T. (1988). Listening. Oxford: Oxford University Press.

Arsyad, A. (2014). Media Pembelajaran. Jakarta: Raja Grafindo Persada.

Aryana, S. \& Apsari, Y. (2018). Analyzing the Teacher's Difficulties in Teaching Listening. ELTIN Journal, 6(2), 100-106

Astuti, W. (2020). Pengembangan Multimedia Pembelajaran Menyimak Berdasarkan Strategi Metakognitif untuk Pemelajar Bahasa Indonesia bagi Penutur Asing (BIPA) Tingkat Madya. Thesis. Yogyakarta: Universitas Negeri Yogyakarta. Unpublished.

Azizah, R. F., HS, W., Lestari, I. (2012). Pembelajaran Bahasa Indonesia bagi Penutur Asing (BIPA) program CLS (Critical Language Scholarship) di Fakultas Sastra Universitas Negeri Malang Tahun 2012. Retrieved from https://www.jurnalonline.um.ac.id.

Azmi, B. M., Celik, B., Yidliz, N., \& Tugrul, M. C. (2014). Listening Comprehension Difficulties Encountered by Students in Second Language Learning Class. Journal of Educational and Instructional Studies in the World, 4(4), 1-6.

Brown, H. D. (2004). Language Assessment: Principles and Classroom Practice. New York: Pearson Education.

Kurniawan, K., Puspitasari, D. A., Batubara, D. H., Hernina, H., Larasati, L. (2019). Pelaksanaan Program BIPA dan Hasil Pembelajarannya. Jurnal Bahasa Indonesia bagi Penutur Asing (JBIPA), 1(1), 11-21.

Kusmiatun, A. (2015). Mengenal BIPA (Bahasa Indonesia bagi Penutur Asing) dan Pembelajarannya. Yogyakarta: K-Media.

Kusmiatun, A. (2016). Topik Pilihan Mahasiswa Tiongkok dalam Pembelajaran BIPA Program Transfer Kredit di UNY. Litera, 15(1), 138-146.

Kusmiatun, A. (2019). Pentingnya Tes Kemahiran Berbahasa Indonesia bagi Pemelajar BIPA Bertujuan Akademik. Diksi, 27(1), 8-13.

Kusmiatun, A., Suyitno, I., HS, W., Basuki, I.A. (2017a). Identifying Features of Indonesian for Speakers of 
Other Languages (BIPA) Learning for Academic Purposes. International Journal of Social Sciences \& Educational Studies, 3(4), 197-207.

Kusmiatun, A., Suyitno, I., HS, W., Basuki, I.A. (2017b). Need Assessment of Learning Materials of Indonesian for Academic Purposes for Speakers of Other Languages. Researchers' World: Journal of Arts, Sciences \& Commerce, 8(3), 151-159.

Kusmiatun, A. (2017c). Pembelajaran Bahasa Indonesia bagi Penutur Asing Bertujuan Akademik. Disertation. Malang: Universitas Negeri Malang. Unpublished.

Lestyarini, B. (2017). Dari Mini Project ke Artikel Jurnal Ilmiah: Mengenalkan Proses Penulisan TA untuk Mahasiswa Tiongkok Program Transfer Kredit. Paper presented in Simposium Internasional Pengajaran Bahasa Indonesia bagi Penutur Asing (BIPA) at Yogyakarta. Yogyakarta: Pusat Pengembangan Strategi dan Diplomasi Kebahasaan, Badan Pengembangan dan Pembinaan Bahasa, Kementerian Pendidikan dan Kebudayaan.

McKay, S. M. (2003). Toward an Appropriate EIL Pedagogy: Re-examining Common ELT Assumptions. International Journal of Applied Linguistics, 13(1), $1-22$.

Muliastuti, L. (2017). Bahasa Indonesia bagi Penutur Asing: Acuan Teori dan Pendekatan Pengajaran. Jakarta: Yayasan Pustaka Obor Indonesia.

Nurgiyantoro, B. (2012). Penilaian Pembelajaran Bahasa Berbasis Kompetensi. Yogyakarta: BPFE.

Parkes, J. \& Harris, M. B. (2002). The Purposes of a Syllabus. College Teaching, 50(2), 55-61.

Renukadevi, D. (2014). The Role of Listening in Language Acquisition: The Challenges \& Strategies in Teaching Listening. International Journal of Education and Information Studies, 4(1), 59-63.

Richards, J. C. (2008). Teaching Listening and Speaking: from Theory to Practice. New York: Cambridge University Press.

Rost, M. (2011). Teaching and Researching Listening (2 ${ }^{\text {nd }}$ ed.). United Kingdom: Pearson Education Limited.

Saraswaty, D. R. (2018). Learner's Difficulties \& Strategies in Listening Comprehension. English Community Journal, 2(1), 139-152.
Sari, N. P. A. W., Sutama, I. M., \& Utama, I. D. G. B. (2016). Pembelajaran Bahasa Indonesia bagi Penutur Asing (BIPA) di Sekolah Cinta Bahasa, Ubud, Bali. E-Journal Prodi Pendidikan Bahasa dan Sastra Indonesia, Undiksha, 5,(3).

Smaldino, S. E., Lowther, D. L., \& Russell, J. D. (2012). Instructional Technology and Media for Learning. Boston: Pearson Education Inc.

Sugiyono. (2013). Metode Penelitian Kombinasi (Mixed Methods). Bandung: Alfabeta.

Susilo, J., Rozak, A., \& Juwanda. (2019). Pengembangan Bahan Ajar BIPA Tujuan Akademik. Paper presented in Konferensi Internasional Pengajaran Bahasa Indonesia bagi Penutur Asing (KIPBIPA) $X I$. Yogyakarta: Universitas Gadjah Mada.

Suyitno, I. (2005). Bahasa Indonesia untuk Penutur Asing: Teori, Strategi, dan Aplikasi Pembelajarannya. Yogyakarta: Grafika Indah.

Suyitno, I. (2008). Norma Pedagogis dan Analisis Kebutuhan Belajar dalam Pembelajaran Bahasa Indonesia untuk Penutur Asing (BIPA). Diksi. 15(1), 111-119.

Tokatli, A. M. \& Kesli, Y. (2009). Syllabus: How Much Does It Contribute to the Effective Communication with the Students?. Proceedings of the World Conference on Educational Sciences.

Tomlinson, B. (1998). Materials Development in Language Teaching. Cambridge: Cambridge University Press.

Vandergrift, L. \& Goh, C. C. M. (2009). Teaching and Testing Listening Comprehension. In M. H. Long \& C.J. Doughty (Eds.), The Handbook of Language Teaching (pp.395-408). United Kingdom: Wiley Blackwell.

Yusnida, D., Muslem, A., \& Manan, A. (2017). A Study of Teaching Listening. English Education Journal, (8)4, 439-456.

Zhang, Y. (2012). The Impact of Listening Strategy on Listening Comprehension. Theory and Practice in Language Studies, 2(3), 625-629. 